\title{
The fuzzy goal programming approach to production planning of intermediate gear spare parts: a case study
}

Aulia Ishak ${ }^{*}$, Poltak Nababan

Department of Industrial Engineering, Universitas Sumatera Utara, Jalan Dr. T. Mansur No.9, Medan, Sumatera Utara 20222, Indonesia

\begin{tabular}{l} 
ARTICLE INFORMATION \\
\hline Article history: \\
Received: March 21, 2020 \\
Revised: June 19, 2020 \\
Accepted: December 24, 2020 \\
\hline
\end{tabular}

Keywords:

Production planning

Fuzzy goal programming

Spare parts

\section{A B S T R A C T}

Production planning has an important role in the company's business processes. A company engaged in the manufacture of intermediate gear parts has a problem in optimizing its production system. The production planning system that occurs is still based on predictions from decision-makers. This study aims to optimize the production planning system to maximize the $15 \mathrm{~T}$ intermediate gear spare parts' production capacity and the 30T intermediate gear spare parts. Optimization of production planning uses the fuzzy goal programming method to optimize objectives based on existing constraints such as working hours, profit tolerance values, and demand tolerance values. The results showed that the use of fuzzy goal programming was able to increase the production level by 2.765 , with an increase in profit of $2.57 \%$. Fuzzy goal programming implementation provides an optimal solution in increasing profits in accordance with company goals based on the constraints that occur.

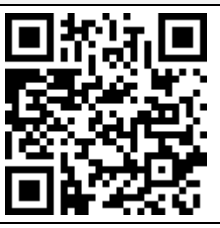

This is an open-access article under the CC-BY-NC-SA license.

*Corresponding Author

Aulia Ishak

E-mail: aulia.ishak@usu.ac.id

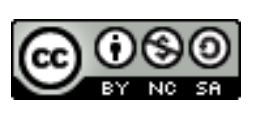

(c) 2020 Some rights reserved

\section{INTRODUCTION}

Production planning is an important process in manufacturing to plan production activities that are efficient in achieving company goals [1]. Production planning requires coordination from management in organizing its resources related to a defined product and directing or regulating the movement of materials (materials, parts/components/sub-assemblies, and products) through the entire production cycle [2]. This process has challenges in facing uncertain future demand in determining optimal production [3]. The uncertainty factor makes production planning require a proper analysis based on existing resources and its ability to distribute its products. Production planning also requires cooperation between functions to achieve maximum profit [4] and minimize inventory levels.

Fuzzy goal programming is a tool that can be used to plan production planning. The goal programming concept is to minimize deviations from the actual results achieved based on the priority scale [5]. The goal programming model functions as a decision-making tool in setting multiple goals simultaneously [6] by including uncertainty and imprecision [7], [8]. Goal programming is effective in production planning because it can solve conflicting obstacles such as manufacturing, product, and consumer aspects.

The fuzzy goal programming model was 
developed to optimize decision-making by minimizing the lower deviation variable [9]. This model combines inaccuracies in data input and the level of target objectives with a hierarchy of objectives based on the analysis of fuzzy relationships between paired interests between objectives [10]. This method effectively helps decisions about production planning related to minimizing raw material costs [11], production costs [12], [13], and profit optimization [14], [15].

XYZ Company deals with the manufacture of machinery/spare parts for palm oil mills, which one of the products of this company is medium gear spare parts. There are two types of intermediate gear spare parts on the Digester engine: the $15 \mathrm{~T}$ intermediate gear spare parts and the 30T intermediate gear spare parts. The production planning system in use today is based solely on the predictions of decision-makers. This system is considered unable to optimize production capacity based on cycle time and the benefits of each product. This study aims to optimize production capacity with the fuzzy goal programming approach. The fuzzy goal programming results are expected to be able to optimize the level of profit from intermediate gear spare parts products.

\section{RESEARCH METHODS}

This research is a descriptive study to assist in operational decision making. This study uses primary data, including processing time and product production (May 2018-April 2019), and secondary data, namely sales and demand data, costs and selling prices, available working hours, and product benefits. Data collection is done by making direct observations of real conditions on the production floor with a stopwatch and interviews or company records. Data processing using LINGO 17.1 software.

The fuzzy goal programming method is also useful when used to determine the optimal combination of products and, at the same time, achieve the desired goals of the company. In the Fuzzy goal, programming presented a pair of variables called "variable deviational" and serves to accommodate deviations or deviations in the segment's value if we have an equation constraint to the value of the right segment. Functional constraints become a limitation for the maximization or minimization of the objective function. In the fuzzy goal programming model, these constraints realize the goals to be achieved [16]. This study uses two variables: the dependent variable is the
15T intermediate gear spare parts, and the 30T intermediate gear spare parts, and the independent variables are the number of demands, the number of production, production cost, selling price, and work time. In production planning, demand forecasting is used as an initial stage of production planning to determine future demand.

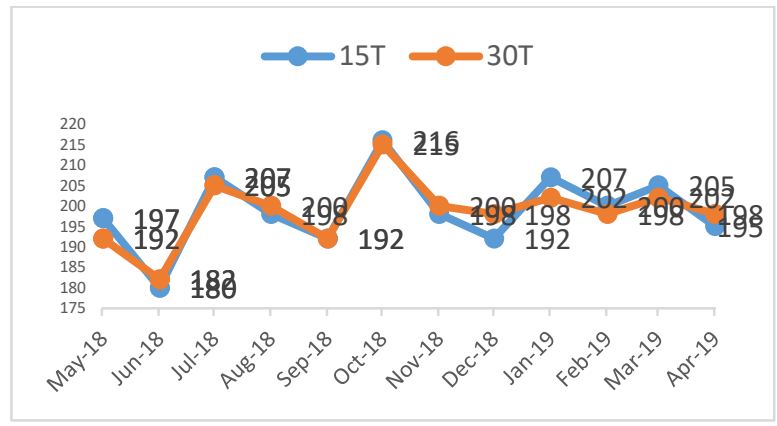

Fig. 1. Historical data patterns

The initial step in fuzzy goal programming projects the amount of production based on the smallest error rate. This study uses the time series method because historical data shows a cyclical pattern (Fig. 1). The time series method is using to analyze data series, which is a function of time [17].

$Y^{\prime}=a+b \sin \left(\frac{2 \pi x}{n}\right)+c \cos \left(\frac{2 \pi x}{n}\right)$

Where $Y^{\prime}=$ number of product forecasts, $n=$ number of period, $\mathrm{x}=$ period of forecasting, and $a, b, c=$ variable of forecasting.

The formation of a fuzzy goal programming model requires decision variables, objective functions to be achieved, constraint functions, and tolerance values. This study's decision variables are $\mathrm{X} 1=$ Number of $15 \mathrm{~T}$ intermediate gear spare parts products and $\mathrm{X} 2=$ Number of $30 \mathrm{~T}$ intermediate gear spare part products. The objective function to be achieved $(\max T)$ with $\mathrm{T}=$ fuzzy membership function value, $\mathrm{Pi}=$ Goals to be achieved, $\mathrm{d} 1+=$ positive deviation, and $\mathrm{i}-=$ negative deviation.

$\operatorname{Max} T=P 1(d 1+\ldots+d 1-)+P 2(d 2+\ldots+d 2-)+\ldots$. $+P i(d i++d i)$

Constraint functions relate to the availability of working hours in the intermediate gear spare parts production process; the company has set working hours.

al $X 1+d i++d i-<=Y i$

Where, $\mathrm{di}+=$ positive deviation, $\mathrm{di}-=$ negative 
deviation, $\mathrm{Xi}=$ number of variables $\mathrm{X}$, and $\mathrm{Yi}=$ number of variables $\mathrm{Y}$

Tolerance values relate to profit and the rate of decrease/increase in the projected demand.

$Z(x)-\left(Z^{*}-\bar{Z}\right) \mathrm{T} \geq \bar{Z}$

Where, $Z^{*}=$ maximum income tolerance limit, $\mathrm{T}=$ fuzzy membership function value and $\mathrm{Z}^{-}=$ minimum income tolerance limit.

Based on several predetermined variables, a fuzzy goal programming model can be formed $(\operatorname{Max} \mathrm{T})$ with $\mathrm{d}_{1}{ }^{+}=$positive deviation, di-= negative deviation, and $\mathrm{T}=$ Fuzzy membership function value.

$\operatorname{Max} T=d_{1}{ }^{+}+d_{2}{ }^{+}+d_{3}{ }^{+}+d_{4}{ }^{+}+d_{5}{ }^{+}+d_{6}{ }^{+}+d_{7}{ }^{+}+d_{8}{ }^{+}$

\section{RESULTS AND DISCUSSION}

This research focuses on two intermediate gear spare parts on the Digester engine: the 15T intermediate gear spare parts and the 30T intermediate gear spare parts. Production planning forecasting is based on historical data for the May 2018-April 2019. Based on the calculations using the times series method, the demand forecasting for the May 2019-April 2020 intermediate gear type is obtained (Table 1).

Table 1. Forecasting result for demand intermediate gear spare parts

\begin{tabular}{ccc}
\hline \multirow{2}{*}{ Period } & $\begin{array}{r}\text { Forecasting results (unit) } \\
\text { 15T }\end{array}$ & 30T \\
\hline May-19 & 166 & 160 \\
Jun-19 & 168 & 153 \\
Jul-19 & 170 & 155 \\
Aug-19 & 169 & 164 \\
Sep-19 & 167 & 175 \\
Oct-19 & 165 & 159 \\
Nov-19 & 166 & 160 \\
Dec-19 & 168 & 153 \\
Jan-20 & 170 & 155 \\
Feb-20 & 169 & 164 \\
Mar-20 & 167 & 170 \\
Apr-20 & 165 & 169 \\
\hline
\end{tabular}

Forecasting results are then optimized using fuzzy goal programming. The formulation of the fuzzy goal programming model functions. The initial steps are to determine decision variables, goal functions, constraint functions for working hours, profit tolerance values, and demand tolerance values. Decision variables are variables that want to optimize their output by meeting several constraint criteria. Decision variables on optimal production planning are $\mathrm{X} 1=$ Number of 15T intermediate gear spare part products, and X2 $=$ Number of 30T intermediate gear spare part products.

The objective function to be achieved using the fuzzy goal programming method is to maximize profits and meet customer demand. The company has set working hours for the availability of working hours in the intermediate gear spare parts production process (Table 2).

Table 2. Cycle time of sparepart intermediate gear

\begin{tabular}{|c|c|c|}
\hline \multicolumn{2}{|c|}{$\begin{array}{l}\text { Cycle time of spare parts } \\
\text { intermediate gear (minutes) }\end{array}$} & \multirow{2}{*}{$\begin{array}{l}\text { Total work hours } \\
\text { applicable } \\
\text { (minutes) }\end{array}$} \\
\hline Type 15T & Type 30T & \\
\hline 4.54 & 4.34 & 2880 \\
\hline 13.35 & 13.05 & 5760 \\
\hline 2.25 & 2.41 & 7200 \\
\hline 49.45 & 48.94 & 20160 \\
\hline 22.69 & 21.39 & 11520 \\
\hline 3.03 & 2.98 & 14400 \\
\hline 11.30 & 11.32 & 11520 \\
\hline 0.74 & 0.91 & 18720 \\
\hline
\end{tabular}

Based on Table 2, the formula for constraint functions for working hours is as follows:

$4.54 X 1+4.34 X 2+d 1--d 1+\leq 2880$

$13.35 X 1+13.05 \times 2+d 2--d 2+\leq 5760$

$2.25 X 1+2.41 X 2+d 3--d 3+\leq 7200$

$49.45 X 1+48.94 X 2+d 4--d 4+\leq 20160$

$22.69 X 1+21.39 X 2+d 5--d 5+\leq 11520$

$3.03 \times 1+2.98 \times 2+d 6--d 6+\leq 14400$

$11.30 X 1+11.32 \times 2+d 7--d 7+\leq 11520$

$0.74 X 1+0.91 X 2+d 8--d 8+\leq 18720$

Determination of profit tolerance values based on interviews with the company, each intermediate gear spare part unit's profit is $\mathrm{Rp}$. 48,000 for intermediate gear spare parts type 15T and Rp. 49,000 for intermediate gear spare parts type $30 \mathrm{~T}$, and the company wants a profit of at least Rp. 16,000,000. The largest production capacity is 170 unit for intermediate gear spare parts type 30T and 175 unit intermediate gear spare parts type $30 \mathrm{~T}$

$$
\begin{aligned}
\text { Maximum profit } & =48,000 \times 170)+(49,000 \times 175) \\
& =\mathrm{Rp} 16,735,000
\end{aligned}
$$

The company does not expect a decline in profit, so the fuzzy linear up function is used, which can be seen in Fig. 2. 


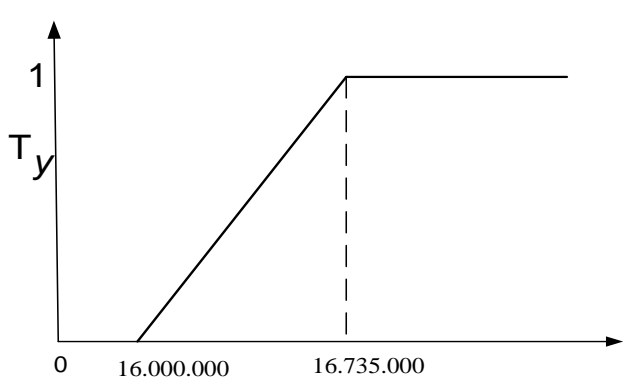

Fig. 2. Fuzzy membership function for profit

So the formulation is:

$Z(x)-\left(Z^{*}-Z \overline{)} T \geq Z^{-}\right.$

$48000 X 1+49000 X 2-(16735000-16000000) T \geq$ 16000000

$48000 X 1+49000 X 2-735000 T \geq 16000000$

$48 X 1+49 X 2-735 T \geq 16000$

Determination of demand tolerance values a decrease and increase in demand, so the fuzzy triangular function describes the increase and decrease in demand (Fig. 3 and Fig. 4). Tolerance values of spare parts intermediate gear type $15 \mathrm{~T}$ for May 2019, are:

Lower tolerance value $=$ forecasting result $-(8 \%$

$$
\begin{aligned}
& x \text { forecasting result) } \\
= & 166-13 \\
= & 153
\end{aligned}
$$

Top tolerance value $=$ forecasting results $+(6 \%$ $x$ forecasting results)

$$
\begin{aligned}
& =166+10 \\
& =176
\end{aligned}
$$

Tolerance values of spare parts intermediate gear type 30T for May 2019, are:

Lower tolerance value $=$ forecasting result $-(8 \%$

$$
\begin{aligned}
& x \text { forecasting result) } \\
= & 160-10 \\
= & 150
\end{aligned}
$$

Top tolerance value $=$ forecasting results $+(6 \%$ $x$ forecasting results)

$$
\begin{aligned}
& =160+8 \\
& =168
\end{aligned}
$$

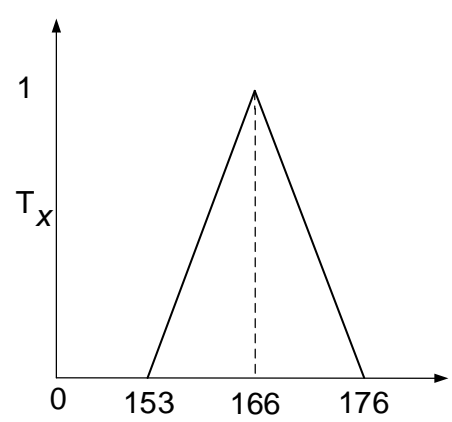

Fig. 3. Fuzzy membership function $15 \mathrm{~T}$

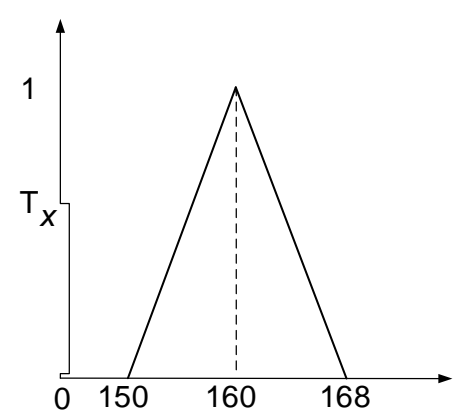

Fig. 4. Fuzzy membership function $30 \mathrm{~T}$

Based on the lower tolerance value and top tolerance value, the formula for demand tolerance values in May 2019 is:

$D(x)-\left(D^{*}-D \overline{)} T \geq D^{-}\right.$, and

$D(x)+\left(D^{-}-D^{*}\right) T \leq D^{-}$

$X 1-13 T \geq 153$

$X 1+10 T \leq 176$

$X 2-10 T \geq 150$

$X 2+8 T \leq 168$

Based on the stipulated conditions, the formulation of the achievement function for the May 2019 fuzzy goal programming method is as follows:

$$
\begin{aligned}
& \text { Max T }=d_{1}{ }^{+}+d_{2}{ }^{+}+d_{3}{ }^{+}+d_{4}{ }^{+}+d_{5}{ }^{+}+d_{6}{ }^{+}+ \\
& d_{7}{ }^{+}+d_{8}^{+} \\
& \text {Subject to } \\
& 48 X 1+49 X 2-735 T>=16000 \\
& X 1-13 T>=153 \\
& X 1+10 T<=176 \\
& X 2-10 T>=150 \\
& X 2+8 T<=168 \\
& 4.54 X 1+4.34 X 2+d 1^{-}-d 1^{+} \leq 2880 \\
& 13.35 X 1+13.05 X 2+d 2^{-}-d 2^{+} \leq 5760 \\
& 2.25 X 1+2.41 X 2+d 3^{-}-d 3^{+} \leq 7200 \\
& 49.45 X 1+48.94 X 2+d 4^{-}-d 4^{+} \leq 20160 \\
& 22.69 X 1+21.39 X 2+d 5^{-}-d 5^{+} \leq 11520 \\
& 3.03 X 1+2.98 X 2+d 6^{-}-d 6^{+} \leq 14400 \\
& 11.30 X 1+11.32 X 2+d 7^{-}-d 7^{+} \leq 11520 \\
& 0.74 X 1+0.91 X 2+d 8^{-}-d 8^{+} \leq 187200 \\
& 0 \leq T \leq 1
\end{aligned}
$$

The achievement function that has been formulated can be calculated using LINGO 17.1 software to obtain the optimum production amount for each product type. The results will appear in the report window showing the calculation results for May 2019 (Fig. 5). Recapitulation of the optimal production planning calculation results of intermediate gear spare parts using 
LINGO 17.1 software is shown in Table 3.

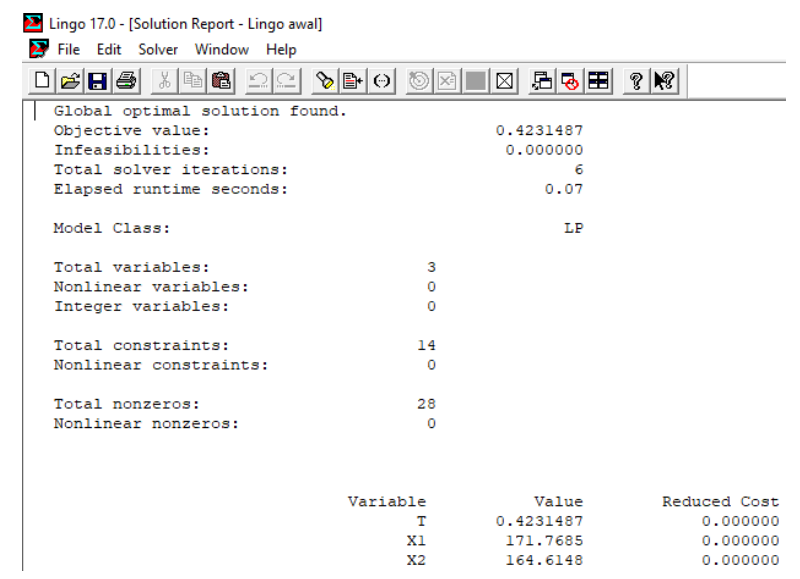

Fig. 5. Display calculation results with LINGO 17.1. software

Using LINGO software, calculation results show that production planning in May 2019 is 172 units for the 15T intermediate gear spare parts and 165 units for 30T intermediate gear spare parts (Table 3). These results indicate an increase in production capacity from the previous plan, namely 166 units for the $15 \mathrm{~T}$ intermediate gear spare parts and 160 units for 30T intermediate gear spare parts. From May 2019 to April 2020, there was an increase in production by 112 units or $2.76 \%$ from the planning time series method. Optimizing production capacity by streamlining each product's cycle time can increase worker productivity at a fixed cost. This shows that the implementation of fuzzy goal programming can minimize production costs [18], [19] because it can increase production results at the same cost.

Table 3. Production planning results with fuzzy goal programming

\begin{tabular}{|c|c|c|}
\hline \multirow{2}{*}{ Period } & \multicolumn{2}{|c|}{ Forecasting planning (unit) } \\
\hline & $15 \mathrm{~T}$ & 30T \\
\hline May-19 & 172 & 165 \\
\hline Jun-19 & 175 & 159 \\
\hline Jul-19 & 176 & 160 \\
\hline Aug-19 & 172 & 168 \\
\hline Sep-19 & 168 & 177 \\
\hline Oct-19 & 169 & 171 \\
\hline Nov-19 & 172 & 164 \\
\hline Dec-19 & 175 & 159 \\
\hline Jan-20 & 176 & 160 \\
\hline Feb-20 & 172 & 168 \\
\hline Mar-20 & 169 & 172 \\
\hline Apr-20 & 168 & 172 \\
\hline
\end{tabular}

Table 4. Achievement of profit (thousand)

\begin{tabular}{|c|c|c|c|c|}
\hline \multirow[t]{2}{*}{ Period } & \multicolumn{2}{|c|}{$\begin{array}{c}\text { Fuzzy goal } \\
\text { programming }\end{array}$} & \multicolumn{2}{|c|}{$\begin{array}{c}\text { Times series } \\
\text { method }\end{array}$} \\
\hline & $15 \mathrm{~T}$ & 30T & $15 \mathrm{~T}$ & 30T \\
\hline May-19 & 8,256 & 8,085 & 7,968 & 7,848 \\
\hline Jun-19 & 8,400 & 7,791 & 8,064 & 7,513 \\
\hline Jul-19 & 8,448 & 7,840 & 8,160 & 7,615 \\
\hline Aug-19 & 8,256 & 8,232 & 8,112 & 8,052 \\
\hline Sep-19 & 8,064 & 8,673 & 8,016 & 8,575 \\
\hline Oct-19 & 8,112 & 8,379 & 7,920 & 8,232 \\
\hline Nov-19 & 8,256 & 8,036 & 7,968 & 7,791 \\
\hline Dec-19 & 8,400 & 7,791 & 8,064 & 7,513 \\
\hline Jan-20 & 8,448 & 7,840 & 8,160 & 7,615 \\
\hline Feb-20 & 8,256 & 8,232 & 8,112 & 8,052 \\
\hline Mar-20 & 8,112 & 8,428 & 8,016 & 8,330 \\
\hline Apr-20 & 8,064 & 8,428 & 7,920 & 8,285 \\
\hline \multirow{2}{*}{ Total } & 99,072 & 97,755 & 96,480 & 95,421 \\
\hline & \multicolumn{2}{|c|}{196,827} & \multicolumn{2}{|c|}{191,901} \\
\hline
\end{tabular}

An increase in the amount of production indirectly has an impact on increasing company profits. Based on May 2019 - April 2020, it shows an increase in profits of $2.57 \%$ or Rp. 4,926 (Table 4). The results achieved correspond to an increase in revenue in the cement industry by 2.02 [20] and a maximum profit increase of $\$ 666825.5$ in the production of vehicle spare parts [21] from the implementation of fuzzy goal programming. This shows that the implementation of fuzzy goal programming can increase the level of company profits in accordance with the objectives set. The use of actual data in the formation of fuzzy programming models is useful in obtaining rational benefits and costs [22]. The fuzzy Goal Programming method is able to optimize a problem with various objectives based on existing constraints.

\section{CONCLUSION}

The results of forecasting the demand for intermediate gear spare parts in May 2019 - April 2020 show a demand trend based on the cycle pattern for each type of intermediate gear spare parts $15 \mathrm{~T}$ and 30T. The fuzzy function to the number of requests is triangular fuzzy because of the increase and decrease in demand, and the fuzzy function to profit is the fuzzy linear increase. Based on the results of processing with the fuzzy goal programming method, optimization of the production planning for intermediate gear 
spare parts can increase the production capacity by $2.76 \%$ and increase profits by $2.57 \%$. Research is still based on internal factors of production, such as the level of working hours, profit, and demand tolerance values. Future research could be used for short-term and intermediate production planning in other continuous process industries. The number of fuzzy goals can be increased based on the decision maker's desirability.

\section{REFERENCES}

[1] E. B. Tirkolaee, A. Goli, and G.-W. Weber, "Multi-objective Aggregate Production Planning Model Considering Overtime and Outsourcing Options Under Fuzzy Seasonal Demand," in Advances in manufacturing II, Springer, 2019, pp. 8196, doi: 10.1007/978-3-030-18789-7_8.

[2] A. Ishak, Manajemen Operasi. Medan: USU Press, 2010.

[3] R. Ramezanian, D. Rahmani, and F. Barzinpour, "An aggregate production planning model for two phase production systems: Solving with genetic algorithm and tabu search," Expert Syst. Appl., vol. 39, no. 1, pp. 1256-1263, 2012, doi: 10.1016/j.eswa.2011.07.134.

[4] S. Komsiyah, Meiliana, and H. E. Centika, "A Fuzzy Goal Programming Model For Production Planning in Furniture Company," Procedia Comput. Sci., vol. 135, pp. 544-552, 2018, doi: 10.1016/j.procs.2018.08.207.

[5] A. K. Bhargava, S. R. Singh, and D. Bansal, "Fuzzy Goal Programming techniques for production planning in industry," Int. J. Comput. Appl. Technol. Res., vol. 4, no. 2, pp. 92-96, 2015. Available:

http://ijcatr.com/archives/volume4/issue2/ ijcatr04021002.pdf.

[6] M. Sadeghi, S. H. Razavi Hajiagha, and S. S. Hashemi, "A fuzzy grey goal programming approach for aggregate production planning," Int. J. Adv. Manuf. Technol., vol. 64, no. 9-12, pp. 17151727, Feb. 2013, doi: 10.1007/s00170012-4135-y.

[7] A. H. Kvanli, "Financial planning using goal programming," Omega, vol. 8, no. 2, pp. 207-218, 1980, doi: 0.1016/03050483(80)90025-0.

[8] D. Bouyssou, "Modelling Inaccurate
Determination, Uncertainty, Imprecision Using Multiple Criteria," in Improving decision making in organisations, Springer, 1989, pp. 78-87, doi: 10.1007/978-3-642-49298-3_8.

[9] A. Biswas and N. Modak, "A Fuzzy Goal Programming Approach for Fuzzy Multiobjective Stochastic Programming through Expectation Model," in International Conference on Mathematical Modelling and Scientific Computation, Springer, 2012, pp. 124-135, doi: 10.1007/978-3-642-28926-2 14.

[10] S. A. Torabi and M. Moghaddam, "Multisite integrated production-distribution planning with trans-shipment: a fuzzy goal programming approach," Int. J. Prod. Res., vol. 50, no. 6, pp. 1726-1748, Mar. 2012, doi: 10.1080/00207543.2011.560907.

[11] D. Petrovic and O. Aköz, "A fuzzy goal programming approach to integrated loading and scheduling of a batch processing machine," J. Oper. Res. Soc., vol. 59, no. 9, pp. 1211-1219, Sep. 2008, doi: $10.1057 /$ palgrave.jors.2602467.

[12] A. F. da Silva and F. A. S. Marins, "A Fuzzy Goal Programming model for solving aggregate production-planning problems under uncertainty: A case study in a Brazilian sugar mill," Energy Econ., vol. 45, pp. 196-204, 2014, doi: 10.1016/j.eneco.2014.07.005.

[13] M. Mekidiche, M. Belmokaddem, and Z. Djemmaa, "Weighted additive fuzzy goal programming approach to aggregate production planning," Int. J. Intell. Syst. Appl., vol. 5, no. 4, p. 20, 2013. Available: http://www.mecs-press.net/ijisa/ijisa-v5n4/IJISA-V5-N4-2.pdf.

[14] S. H. Mirkarimi, R. Joolaie, F. Eshraghi, and F. S. B. Abadi, "Application of fuzzy goal programming in cropping pattern management of selected crops in Mazandaran province (case study Amol township)," Int. J. Agric. Crop Sci., vol. 6, no. 15, p. 1062,2013 . Available: https://www.cabdirect.org/cabdirect/abstra ct/20143013052.

[15] V. Ghasemi, "A Fuzzy Goal Programming for Modeling Optimal Production Capacity of Shetabkar Company," Asian J. Res. Bus. Econ. Manag., vol. 5, no. 4, pp. 249-261, 2015, doi: 10.5958/2249- 
7307.2015.00102.4.

[16] S. S. Rao, Engineering optimization: theory and practice. New Jersey:John Wiley and Sons, 2019. Available: https://books.google.co.id/books?id=oG21 DWAAQBAJ.

[17] A. V. Penenko, "A Newton-Kantorovich Method in Inverse Source Problems for Production-Destruction Models with Time Series-Type Measurement Data," Numer. Anal. Appl., vol. 12, no. 1, pp. 51-69, Jan. 2019, doi: 10.1134/S1995423919010051.

[18] M. Belmokaddem, M. Mekidiche, and A. Sahed, "Application of a fuzzy goal programming approach with different importance and priorities to aggregate production planning," J. Appl. Quant. methods, vol. 4, no. 3, pp. 317-331, 2009. Available:

http://www.jaqm.ro/issues/volume4 ,issue-

3/pdfs/belmokaddem_mekidiche_sahed.p df.

[19] S. Tyagi, K. Yang, A. Tyagi, and A. Verma, "A Fuzzy Goal Programming Approach for Optimal Product Family Design of Mobile Phones and Multiple-
Platform Architecture," IEEE Trans. Syst. Man, Cybern. Part C (Applications Rev., vol. 42, no. 6, pp. 1519-1530, Nov. 2012, doi: 10.1109/TSMCC.2012.2198056.

[20] M. Modiri, S. Moheb Rabbani, and H. Heidari Gharebolagh, "Influence of fuzzy Goal Programming in Production Optimization Case study: Cement Industry," J. Optim. Ind. Eng., vol. 3, no. 6, pp. 43-52, 2010. Available: http://www.qjie.ir/article_48_12.html.

[21] H. A. Abdelwali, E. E. M. Ellaimony, Y. M. Alhouli, J. M. S. Alrajhi, M. S. Alardhi, and A. E. Murad, "Using Fuzzy Goal Programming Technique to Obtain the Optimum Production of Vehicle Spare Parts, A Case Study," Glob. J. Res. Eng., vol. 15, no. 6, pp. 65-71, 2015. Available: https://www.engineeringresearch.org/inde x.php/GJRE/article/view/1740.

[22] M. Sakawa, I. Nishizaki, and Y. Uemura, "Fuzzy programming and profit and cost allocation for a production and transportation problem," Eur. J. Oper. Res., vol. 131, no. 1, pp. 1-15, 2001, doi: 10.1016/S0377-2217(00)00104-1. 